\title{
Some like it hot: environmental determinism and the pastoral economies of the later prehistoric Eurasian steppe
}

\author{
Robin Bendrey ${ }^{1,2}$
}

\author{
Correspondence: $r$ \\ bendrey@reading.ac.uk \\ ${ }^{1}$ Muséum national d'Histoire \\ naturelle, UMR 7209 du CNRS « \\ Archéozoologie, archéobotanique: \\ sociétés, pratiques et \\ environnements », Département \\ Écologie et Gestion de la \\ Biodiversité, USM 303, Case postale \\ Nº 56 (Bâtiment d'anatomie \\ comparée), 55 rue Buffon, F-75231 \\ Paris cedex 05, France \\ Full list of author information is \\ available at the end of the article
}

\begin{abstract}
Background: Pastoral systems may be envisaged as a product of a number of interacting variables: the characteristics of the animals, the environment, and of the human culture. Animal physiological and behavioural characteristics affect their suitability to different climatic, topographical and ecological environments. This paper attempts to advance our understanding of the environmental factors constraining animal husbandry on the prehistoric Eurasian steppe, an area that exhibits a broad range of environmental conditions, through comparisons of data on archaeological animal bone assemblages and historic and modern herd compositions (specifically the proportions of cattle, sheep/goats and horse).

Results: There are strong biases towards different taxa dependent on region. The consistencies between the later prehistoric animal bone data and the modern and historic livestock herd compositions indicate the constraining role of the environment on the pastoral economies practiced across the Eurasian steppe, in that pastoral strategies appear to be focussing on species best adapted to regional environments. Other patterns may be indicative of socioeconomic trends, such as the relatively low proportions of horse herded in modern times.

Conclusions: The results indicate variability in herd compositions across the study area being influenced in part by regional climatic, topographical and ecological conditions. Thus, it is suggested, that part of the variability seen in herd compositions is environmentally determined, with herders making decisions based on the animals' biological and behavioural characteristics. Better understanding of the environmental constraints on pastoral economies will enable us to address a range of questions relating to past pastoralists, and allow us to better assess the cultural factors at play.
\end{abstract}

Keywords: Pastoralism Archaeozoology, Eurasian steppe, Prehistory, Climate, Domestic animals, Herd compositions

\section{Introduction}

The origins, spread and development of pastoral economies on the Eurasian steppe have been the subject of significant research and debate. Studies, often based on single or multiple sites in particular regions, have tended to draw conclusions without sufficient reference to large-scale variation evident across this vast area. The territories of the Eurasian steppe exhibit a broad range of environments, and we would expect to

(C) 2011 Bendrey; licensee Springer. This is an Open Access article distributed under the terms of the Creative Commons Attribution License (http://creativecommons.org/licenses/by/2.0), which permits unrestricted use, distribution, and reproduction in any medium, provided the original work is properly cited. 
see significant variation in prehistoric animal husbandry according to the characteristics of the environments and the suitability of different animals to these conditions.

Any particular pastoral system may be envisaged as a product of a number of interacting variables: the characteristics of the animals, the environment, and of the human culture. The physiological and behavioural characteristics of the different domestic animal species and breeds affect their suitability to different climatic, topographical and ecological environments (Kerven et al. 1996; Nardone et al. 2006; Temple 1984). Environmental and biological factors which can affect animal populations, especially through their effect on reproduction and mortality, include: environmental temperature, humidity, daylight length, nutrition, water availability, disease, and heredity (Temple 1984). A better understanding of pastoral economies will stem from a consideration of all aspects influencing these systems (Popova 2006).

This short paper contributes to such an understanding through a consideration of variation in animal use in relation to environmental conditions (especially temperature and precipitation). The aim is to consider environmental constraints on the pastoral component of prehistoric economies in terms of the limiting factors on the animals themselves, through a simple comparison of prehistoric domestic animal representation and use across the steppe to modern data on livestock numbers across this region. Patterns which emerge from this comparison will allow for future, more precise, investigations of potential relationships between modern and past species use and climate and vegetation mosaics.

\section{Modern environmental conditions of the Eurasian Steppe}

The Eurasian steppe extends from Hungary in the west, to the mountains of Central Asia in the east. In the north, it is bordered by the forest-steppe, and in the south by the semi-deserts and deserts of Central Asia and the Black and Caspian Seas, with the further vegetation zone of alpine and mountain pastures of the uplands of Central Asia (Kerven et al. 1996; Kremenetski 2003). The natural environment, temperature and precipitation vary considerably across this broad area according to geographical position, altitude and local topography (Kerven et al. 1996; see Table 1 and Figure 1).

The steppe can be divided into two broad climatic regions: with the area west of the Ural Mountains having a continental and temperate climate, and that to the east being continental (Kotova and Makhortykh 2010; Kremenetske 2003). As seen in Table 1 winter temperatures in the eastern steppe can dip as low as around $-30^{\circ} \mathrm{C}$ in the easterly and northerly areas. Winter temperatures in the western steppe are significantly less negative, producing overall long-term annual mean temperatures of around 7 to $9^{\circ}$ $\mathrm{C}$ compared to values of around $0^{\circ} \mathrm{C}$ in the northern regions of the eastern steppe (Table 1). Published data from Kazakhstan concur with the data in Table 1 from sites just to the north and south of this country (de Beurs and Henebry 2004). For example, Petropavlovsk in the north of Kazakhstan has an average yearly temperature of $1.5^{\circ} \mathrm{C}$ and an average precipitation of $366 \mathrm{~mm}$, and desert land on the Syr-Darya in the south of Kazakhstan has an average annual temperature of $9.8^{\circ} \mathrm{C}$ and precipitation of $149 \mathrm{~mm}$ (de Beurs and Henebry 2004).

In general, annual precipitation is higher in the western steppe and in the northern forest-steppe belt compared to the majority of Kazakhstan, Mongolia and the desert regions of Uzbekistan and north west China (Table 1 and Figure 1; Kerven et al. 1996; Krader 1955). The mountains of Central Asia, however, can have relatively high rainfall 
Table 1 Modern variation in air temperature and annual precipitation recorded at GNIP stations along and around the Eurasian steppe [data from the Global Network of Isotopes in Precipitation (GNIP) database (IAEA/WMO 2006)]

\begin{tabular}{|c|c|c|c|c|c|c|c|c|c|c|}
\hline & & GNIP station & country & longitude & latitude & altitude $(\mathrm{m})$ & $\min \left({ }^{\circ} \mathrm{C}\right)^{1}$ & $\begin{array}{l}\text { air temperature } \\
\max \left({ }^{\circ} \mathrm{C}\right)^{1}\end{array}$ & mean $\left({ }^{\circ} \mathrm{C}\right)^{2}$ & $\begin{array}{l}\text { precipitation } \\
(\mathrm{mm})^{2}\end{array}$ \\
\hline \multirow[t]{5}{*}{ western region } & north & Odessa & Ukraine & 30.63 & 46.48 & 64 & -9.8 & 34.4 & 9.4 & 350 \\
\hline & & Har'kov & Ukraine & 36.28 & 49.93 & 148 & -14.4 & 22.5 & 9.4 & 350 \\
\hline & & Saratov & Russia & 46.03 & 51.56 & 166 & -15.8 & 24.8 & 6.8 & 462 \\
\hline & south & Tbilisi & Georgia & 44.95 & 41.68 & 490 & -8.1 & 30 & 13.4 & 521 \\
\hline & & Batumi & Georgia & 41.63 & 41.65 & 6 & 3.8 & 27.1 & 14.6 & 2486 \\
\hline \multirow[t]{6}{*}{ eastern region } & north & Omsk & Russia & 73.38 & 55.01 & 94 & -24.1 & 21.1 & 1.9 & 404 \\
\hline & & Novosibirsk & Russia & 82.9 & 55.03 & 162 & -24.8 & 20.7 & 1.3 & 422 \\
\hline & & Enisejsk & Russia & 92.15 & 58.45 & 98 & -29.6 & 19.8 & -1.2 & 491 \\
\hline & south & Tashkent & Ukbekistan & 69.27 & 41.27 & 428 & -13.4 & 28.9 & 13.3 & 455 \\
\hline & & Wulumuqi & China & 87.62 & 43.78 & 918 & -15.7 & 29.8 & 7.9 & 263 \\
\hline & east & Ulaanbaatar & Mongolia & 106.98 & 47.93 & 1338 & -31.9 & 20.8 & 0.1 & 255 \\
\hline
\end{tabular}

The GNIP stations have been divided into western and eastern regions, according to their longitudinal position in relation to the Ural Mountains, and then into groups within these regions according to their position (No data for Kazakhstan).

Notes:

1- minima and maxima of seasonal temperature variation (not from the same years, as different periods of time sampled for the different sites)

2- long term means 


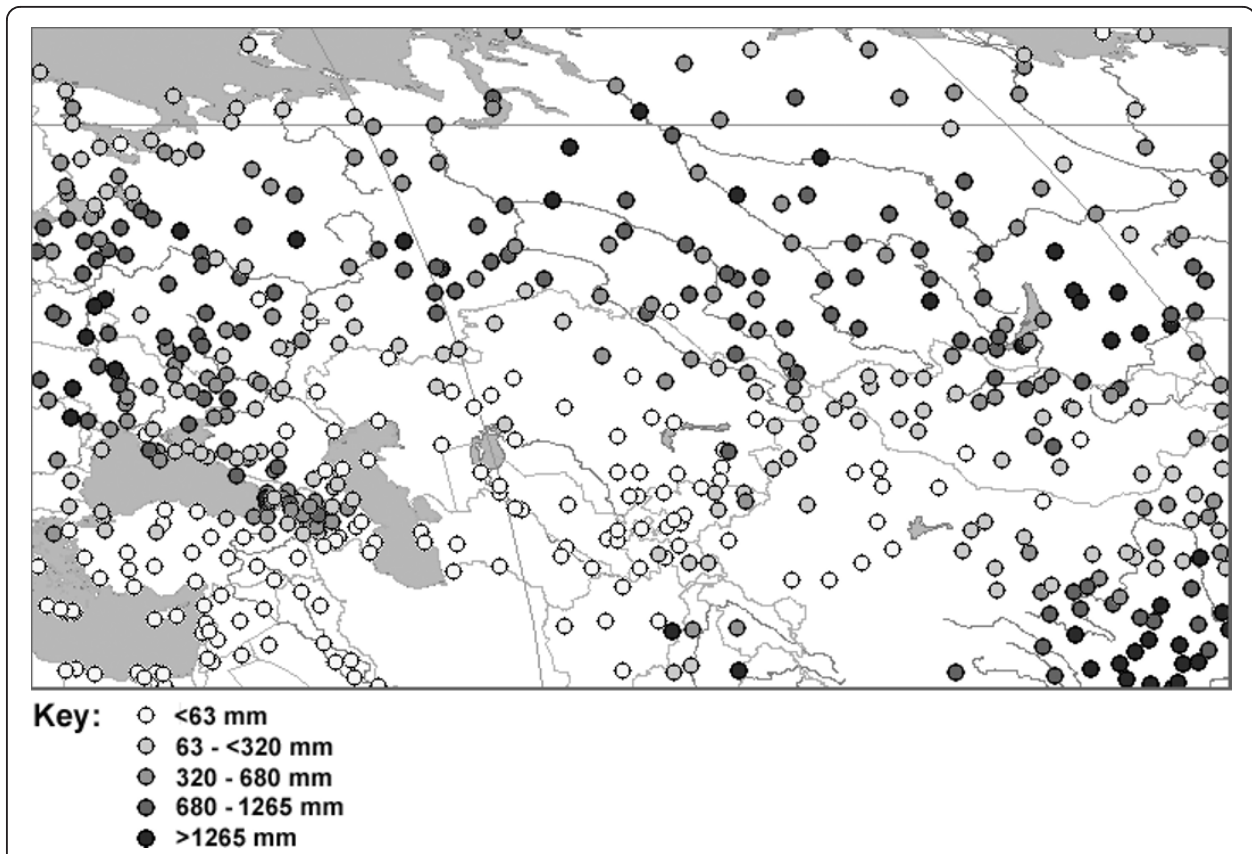

Figure 1 Map showing summer precipitation variation across northern Asia [data for July 1980; data and map from Global Network of Isotopes in Precipitation (GNIP) database (IAEA/WMO 2006)].

- up to $450 \mathrm{~mm}$ per year in the mountains in the south of Kazakhstan according to de Beurs and Henebry (2004). At higher elevations, as in the north, precipitation increases and temperatures decrease (Kerven et al. 1996).

\section{Domestic animals of the Eurasian steppe}

This paper considers the relative proportions of cattle, sheep/goat and horse bones in archaeological assemblages. As the following brief overview of the appearance and spread of domestic livestock outlines, these taxa become common elements of pastoral economies across the Eurasian steppe during later prehistory. Sheep and goats have very similar skeletons (e.g. Boessneck 1969; Payne 1985a), and it is often the case that disarticulated and fragmented bones of these species are not separated during archaeological analysis. For this reason, sheep and goats are treated together as a single taxon in this paper.

Current evidence indicates domestication of sheep, goat, pig and cattle in separate centres of the Fertile Crescent in the Near East between c.9000 and 8000 cal BC (Zeder 2008; Vigne 2011), although other centres of domestication elsewhere in Eurasia are possible, as is known for pigs (Larson et al. 2005; Cucchi et al. 2011). There are several possible routes linking the Near East with the Eurasian steppe, of which the precise contributions of domestic stock to the Eurasian steppes are less than clear. From the Near East, cattle, sheep, goat, and pig were introduced to south-east Europe in the seventh millennium BC (Zeder 2008; Tresset 2011 and Vigne 2011) and, from here, began to appear at the western end of the steppe from the sixth millennium BC (Anthony 2007; Dolukhanov 2002; Dolukhanov 1986a; Zvelebil and Lillie 2000). The Caucasus, lying between the Black and Caspian Seas, is a further route joining the Near East and the western steppes, from where the earliest food-producing economies are known from the sixth millennium BC (Kohl 2007). Domestic sheep, cattle, and 
possibly goat, are reported from the eastern Caucasus in the first half of the 6th millennium BC (Kushnareva 1997). Lastly, there is the route around the eastern side of the Caspian Sea. At around the same time as farming was spreading west into southeast Europe, there also seems to be dispersal eastwards from the Fertile Crescent (Barker 2006; Harris 2010). Domestic sheep and goat appeared in Early-Jeitun levels of the southern Caspian region (southern Turkmenistan) in the late seventh millennium BC, while domestic cattle have been found from Middle- and Late-Jeitun levels (from c.5700 BC) (Harris 2010). Whereas a broad north-south cultural continuity along the eastern side of the Caspian Sea, as far north as the southern Urals, is evidenced previously by Mesolithic microlithic cultures (Matyushin 2003, 1996), the development of the Central Asian deserts in the Holocene acted as a barrier to subsequent human interaction via this route (Dolukhanov 1986b; Hiebert 2002). Contact between the steppe and the areas to the south of the Kyzyl Kum and Kara Kum deserts appears to have been achieved only in the later third millennium BC with the development of mobile pastoralism in the deserts, aided by horses and Bactrian camels (Hiebert 2002; Kohl 2007).

Once established in the western steppes, domestic animals gradually spread eastwards. Domestic cattle, sheep and goats do not become properly established until the early third millennium BC in the Trans-Urals steppe (Koryakova and Epimakhov 2007), and the mid-third millennium BC in the Kazakh steppe (Benecke and von den Driesch 2003; Frachetti 2008; Outram et al. 2011). However, these species do make an earlier, more limited, appearance at Neolithic sites of the southern Urals (Matyushin 2003; 1986; Kosintsev 2006), the Neolithic Atabasar culture of the Kazakh steppe (Benecke and von den Driesch 2003; Kislenko and Tatarintseva 1999) and then the midfourth millennium BC Afanasievo culture of the western Altai (Anthony 2007). Pigs appear in the early second millennium in the forest-steppe of the Ural region (Bolshakov and Kosintsev 1995; Koryakova and Epimakhov 2007) and subsequently, during the Bronze Age, move eastwards along the forest-steppe zone (Kosintsev 2002), but not into the Kazakh steppe to the south of this (Benecke and von den Driesch 2003).

Horse bones are present at sites throughout the later prehistoric western and eastern steppes, however, the identification of the earliest domestication of the horse, and its subsequent spread, is still a much debated and controversial subject (e.g. Anthony 2007; Benecke and von den Driesch 2003; Levine 2005; Olsen 2006). Although there are arguments for earlier, fifth millennium $\mathrm{BC}$, domestication of the horse in the western steppe, recent work has suggested that it is in the mid-fourth millennium $B C$, in the Eneolithic Botai culture of northern Kazakhstan, that we have the earliest good case for the presence of domestic horses (at a time when cattle, sheep and goats are absent from the Kazakh steppe) (Olsen 2006; Outram et al. 2009). However, the horse does not appear to enter widespread use beyond the steppe zone, in Europe and the Near East until the late third millennium BC (Kohl 2007). The other transport animal of significance for pastoral groups on the Eurasian steppe is the camel. Present at a series of Bronze Age sites in southern Central Asia, it is thought that camels may have played a critical role from the Iron Age in the steppe (Kohl 2007). Camels, like pigs, were not present over the entirety of the study region, and it is cattle, sheep/goat and horse, which were, that form the focus of the rest of the paper. 


\section{Materials and methods}

Excavations at archaeological sites across the steppe have produced collections of butchered and fragmented animal bones. These are the remains of meals and other activities, such as craft production and ritual activity, and offer information on domestic animal use by early pastoral communities. Details of such assemblages have been published by various authors (e.g. see below), and here we seek to explore the role of environmental influences on prehistoric pastoral economies through a comparison of this published material over a broad geographical area.

The counts of bones and teeth from these sites cannot be used to directly reconstruct prehistoric herds. Numbers of bones recovered will have been affected by butchery techniques, disposal practices, preservation conditions and other taphonomic factors (Lyman 1994). The carcasses of different species may have been treated differently, for example greater breaking of bones, such as for marrow extraction, could increase fragment counts. Certain skeletal elements may be under-represented if consistently removed for other uses, such as in craft production. Differential preservation at sites can also affect the species ratios recovered, with the bones of smaller animals more susceptible to destruction than those of larger beasts. Variation in deposition and rubbish disposal will also be of significance, and scavenging and chewing of bones by dogs may significantly alter assemblages through the preferential destruction of certain bones. These taphonomic factors, and more, act to limit our ability to reconstruct live herds from simple fragment counts. However, comparative analyses of archaeological assemblages can provide valuable data on animal use and importance in the past. Zooarchaeologists use a range of methods to quantify bones recovered from archaeological sites. The two most commonly used quantification units for published material from the Eurasian steppe are NISP and MNI. NISP is defined as the number of identified specimens per taxon and is an observational unit, whereas MNI is defined as the minimum number of individual animals necessary to account for the set of identified bones (Lyman 1994). MNI is a "derived unit because it may or may not take inter-specimen variation such as age, sex, or size into account" (Lyman 1994). NISP quantifications tend to exaggerate the importance of species whose elements are more readily identified, and minimises the importance of species represented by only a few specimens, whereas MNI exaggerates the presence of rarer animals (Payne 1985b). In the paper presented here it is assemblages quantified using the number of identified specimens (NISP) that have been used as it is a readily comparable unit and is "a relatively uncontroversial expression of the composition of the recovered assemblage" (O'Connor 2010).

A number of spatially discrete published collections of later prehistoric animal bone assemblages are used here (Figures 2 and 3). Later prehistoric (Bronze and Iron Age) assemblages have been chosen as all the main domestic taxa in question (cattle, sheep/ goat and horse) had been domesticated by this point and had been spread throughout the different ecological zones of the Eurasian steppe (see above). The numbers of identified bones of these taxa are totalled for each site, and the percentage contribution of each was calculated. The collections of animal bone assemblages used here range in date and geographical location: 


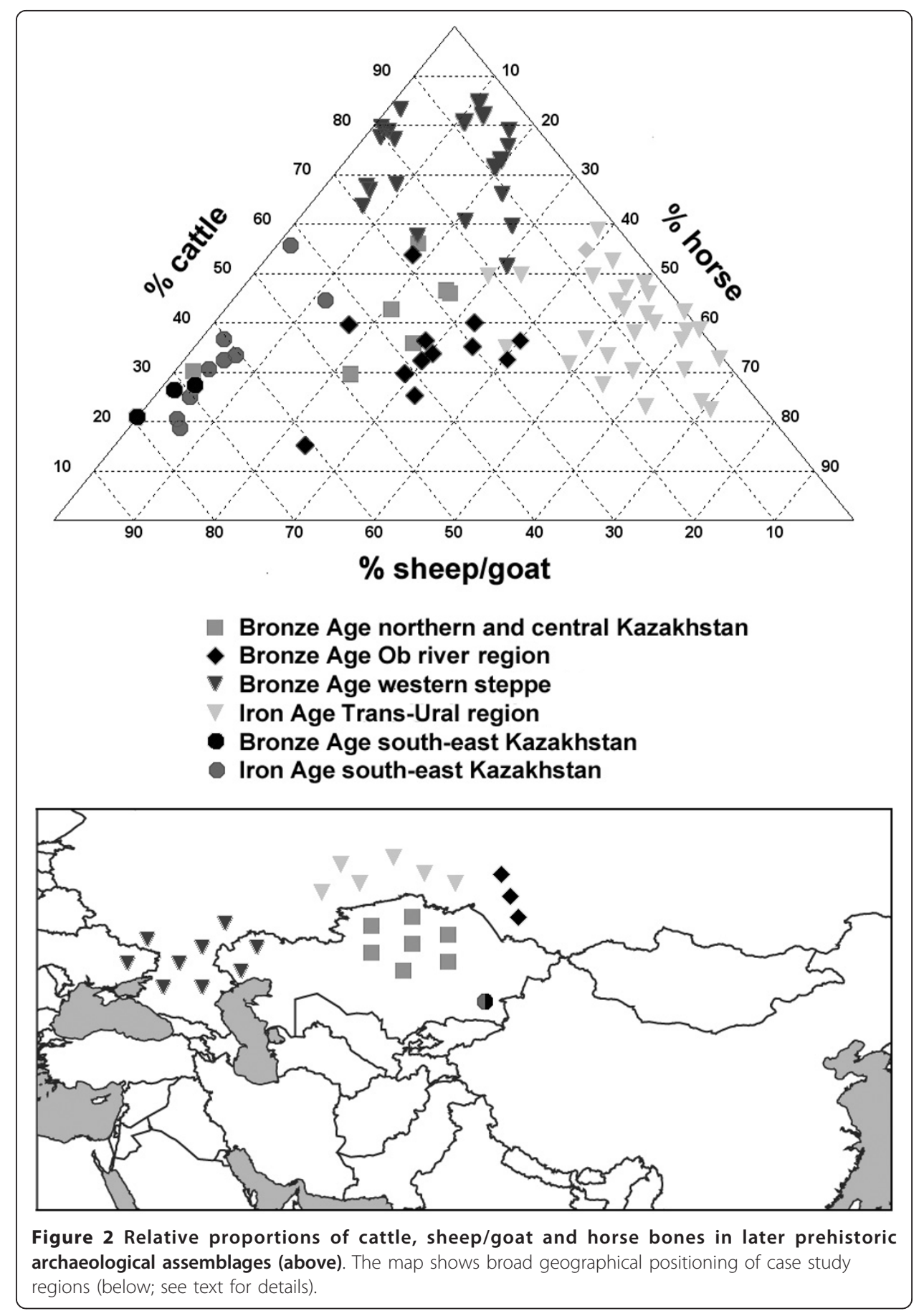

- seven Bronze Age sites from northern and central Kazakhstan, of which six are Late Bronze Age and one Middle-Late Bronze Age (Benecke and von den Driesch 2003, table 6.1);

- thirteen Bronze Age settlements situated in the forest-steppe zone along the $\mathrm{Ob}$ river (Kosintsev 2002, table one); 


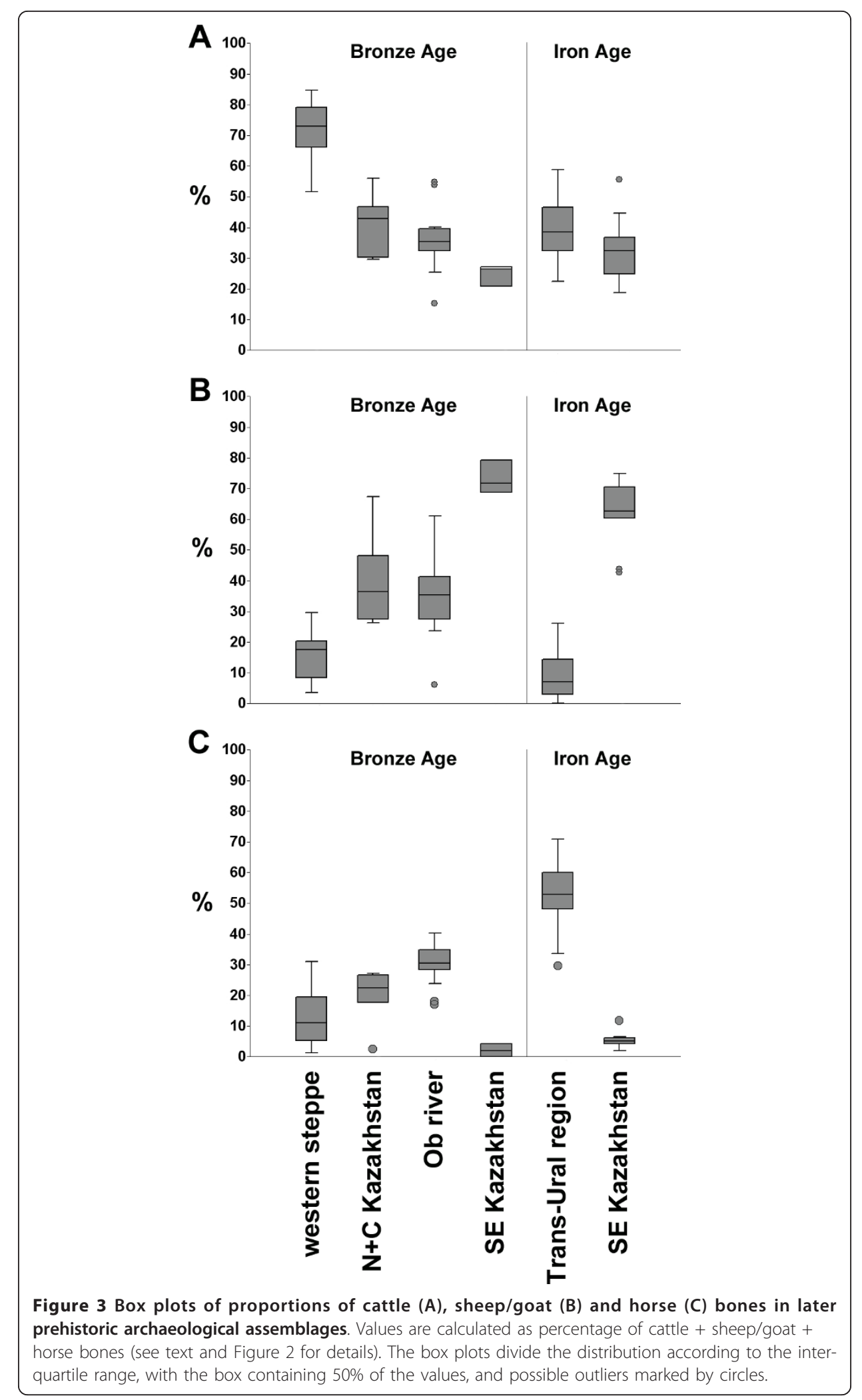


- 21 Late Bronze Age assemblages from western (Azov, Orenburg and West Caspian) steppe zones (four sites of the Abashevo culture, and 17 of the Srubnaya culture) (Morales Muniz and Antipina 2003, table 22.2);

- three Bronze Age (Early, Middle and Late), and two Iron Age habitation phases at the site of Begash in south-east Kazakhstan (Frachetti and Benecke 2009, table one);

- seven further Iron Age sites from south-east Kazakhstan, four from the Talgar region and three from the Tsenganka river (Benecke 2003, tables one and two);

- 28 Iron Age sites from the Trans-Ural and Pre-Ural region (13 Sargat settlements, seven Itkul settlements, and eight Ananyino settlements) (Koryakova and Hanks 2006, tables two, three and four).

The chronology of the assemblages can be broadly divided between the Bronze Age material, dating to the second millennium BC (except for the Early Bronze Age phase from Begash, which dates to the mid-late 3rd millennium) and the Iron Age sites of the first millennium $\mathrm{BC}$.

\section{Modern and historic livestock herds}

The archaeological data are here compared to modern and historic livestock herd variations. As in the archaeological data, the proportional contributions of these taxa are discussed, excluding other livestock present in these countries. Numbers of cattle, sheep/goats and horses have been totalled and their proportional contributions are discussed below.

Figure 4 plots the modern relative proportions of cattle, sheep/goats and horses maintained by countries along the steppe zone for the ten years from 1999 to 2008 . Livestock numbers for the Russian Federation have not been plotted as the data are undifferentiated for its area, and does not allow assessment of geographical variation within the territories covered by this vast country.

Data on species compositions herded by historic groups are also considered (Figure 5). These samples, dating to the nineteenth and early twentieth centuries $\mathrm{AD}$, come from the eastern steppe region (Table 2).

\section{Comparison of species proportions}

Plotting the percentage contributions of cattle, sheep/goat and horse bones reveals that many of the archaeological sites from the separate regions and time periods tend to cluster separately (Figure 2), indicating that we may be able to characterize the economies of these different regions.

The Bronze Age data reveals a west-east trend in the representation of cattle in the archaeological record, with cattle representation highest in the western steppe and lowest in south-east Kazakhstan (Figures 2 and 3A). During the Iron Age, the proportion of cattle bones is slightly greater in the Trans-Ural and Pre-Ural region to the north, than the sites in south-east Kazakhstan. The proportions of sheep/goat bones at Bronze Age sites appears to mirror the situation seen in cattle, with the lowest numbers seen in the western steppes and the highest in south-east Kazakhstan (Figure 3B). In the Iron Age data we see a stark contrast in the percentage of sheep/goat bones between south-east Kazakhstan and the Trans-Ural and Pre-Ural region. 


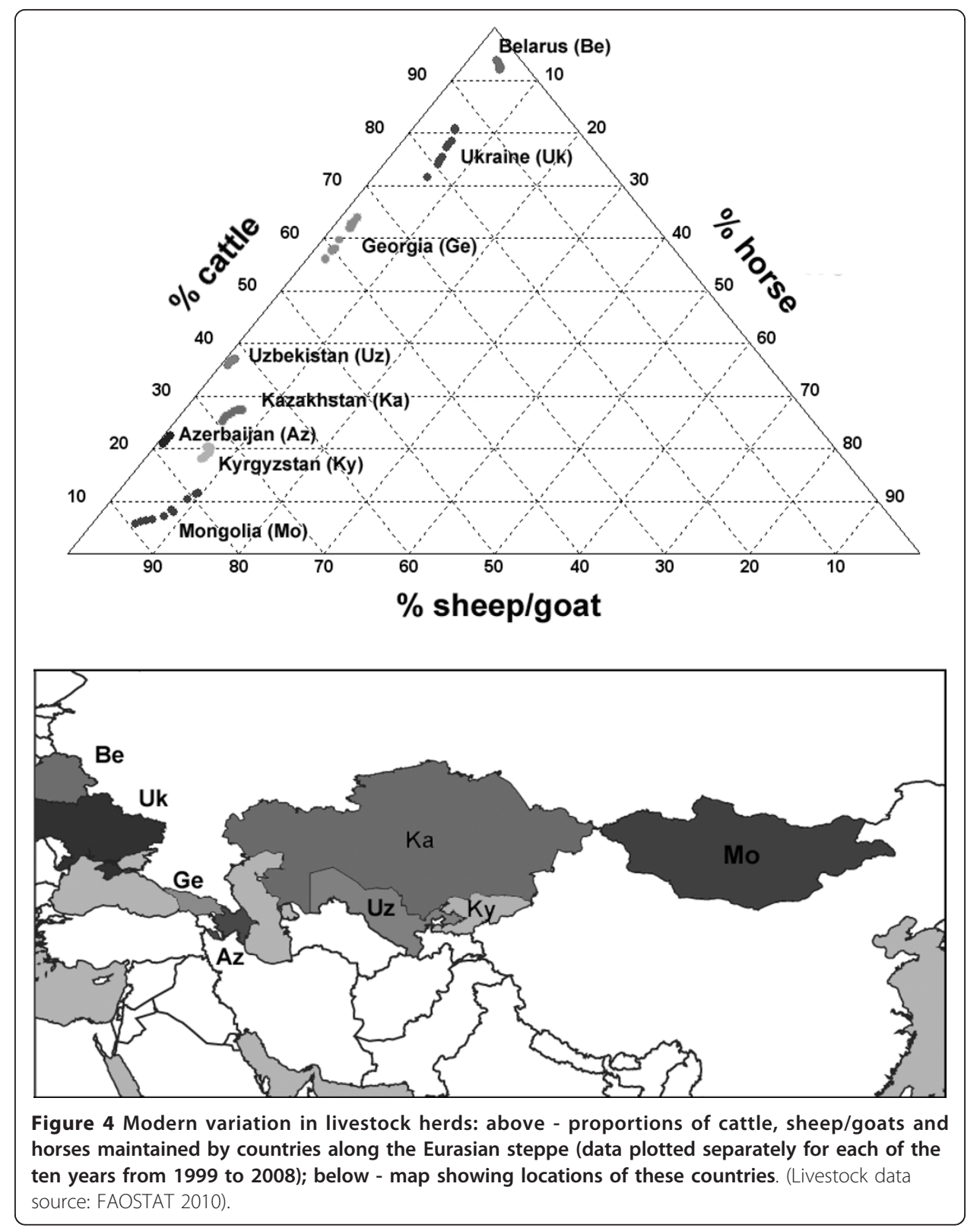

The modern data also present a consistent west-east pattern, with cattle raising common in the west and sheep/goat husbandry in the east (Figure 4). In general, we can see two groups of countries: those with $>50 \%$ cattle, and those with $>50 \%$ sheep/goats. This correlates with broad climatic variations across the steppe zone, in which there is greater precipitation in the west than the east (e.g. Figure 1; Ye 2001).

Cattle require higher quality pasture and more water than sheep or goats. Cattle are not able to conserve water efficiently, nor do they withstand dehydration well, and are not well suited to drought conditions; whereas sheep and goats have higher adaptability to hot and dry environments (Kay 1997; Nardone et al. 2006). Temple (1984) states that cattle need drinking water every day, and once in three days as an absolute minimum, whereas sheep and goats can survive for up to five to seven days without water. Water stress is not just a question of the quantity of precipitation, but also evaporation 


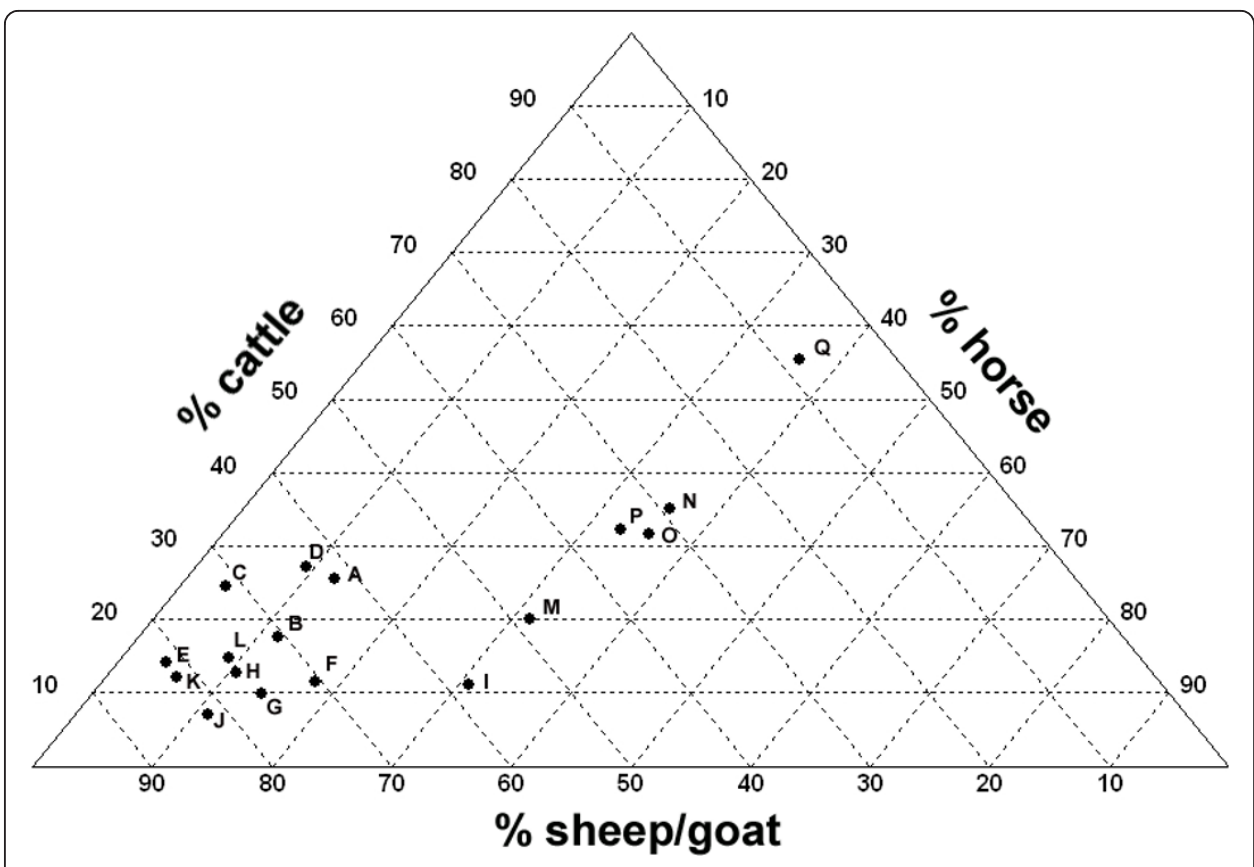

Figure 5 Variation in livestock herds in historical (19th-early 20th century AD) populations from the steppe zone: proportions of cattle, sheep/goats and horses maintained by different groups (see Table 2 for geographical and chronological provenance).

rates, amongst other variables (Lioubimtseva and Henebry 2009). Thornton et al. (2009) discuss the role of temperature on water demand by cattle, and give figures of $\sim 3, \sim 8$, and $\sim 14 \mathrm{~kg}$ of water per $\mathrm{kg}$ of dry matter of feed consumed at $10^{\circ} \mathrm{C}, 30^{\circ} \mathrm{C}$, and $35^{\circ} \mathrm{C}$ ambient temperature respectively. Further, high evapotranspiration rates can have a serious impact on pasture quality (Sternberg et al. 2010). Goats adapt better to harsh environments (Silanikove 2000), and tend to increase relative to sheep under

Table 2 Provenance of historic $\left(19^{\text {th }}\right.$ and early $20^{\text {th }}$ century AD) data presented in Figure 5

\begin{tabular}{|c|c|c|}
\hline code & Sample & reference \\
\hline $\bar{A}$ & Kazakhstan, 1920 & Krader 1955 \\
\hline B & Kirgizia, 1920 & Krader 1955 \\
\hline C & Tadjikistan, 1920 & Krader 1955 \\
\hline D & Uzbekistan, 1920 & Krader 1955 \\
\hline$E$ & Turkmenia, 1920 & Krader 1955 \\
\hline $\mathrm{F}$ & Bukei, 1846 & Krader 1955 \\
\hline G & Bukei, 1849-50 & Krader 1955 \\
\hline $\mathrm{H}$ & Bukei, 1852 & Krader 1955 \\
\hline I & Semipalatinsk, 1876 & Krader 1955 \\
\hline$J$ & Kuldja, 1877 & Krader 1955 \\
\hline K & Sinkiang, 1933 & Krader 1955 \\
\hline$L$ & Tuva, 1931 & Vainshtein 1980 \\
\hline M & Trans-Uralian Bashkirs (Shadrinsk District), early $19^{\text {th }}$ century & Koryakova and Hanks 2006 \\
\hline N & Tyumen District Native Population, early $19^{\text {th }}$ century & Koryakova and Hanks 2006 \\
\hline $\mathrm{O}$ & Yalutorovsk District Native Population, early $19^{\text {th }}$ century & Koryakova and Hanks 2006 \\
\hline$P$ & Native Population of Tarsky District, early $19^{\text {th }}$ century & Koryakova and Hanks 2006 \\
\hline Q & Kazakhs of Kokchetav District, early $19^{\text {th }}$ century & Koryakova and Hanks 2006 \\
\hline
\end{tabular}

Note: (Koryakova and Hanks 2006, table one) tabulate cattle, horse and sheep data (rather than sheep/goat). 
conditions of greater aridity and higher altitude in central Asia (Krader 1955). Undoubtedly there will be cultural factors influencing the use of domestic animals, however, the data presented here indicate cattle and sheep/goat husbandry being significantly affected by environment (precipitation, temperature, topography and ecology) on a broad west-east gradient.

Azerbaijan is the sole country whose modern livestock compositions seem to deviate from the general west-east pattern, plotting close to Kyrgyzstan, with nearly $80 \%$ sheep/goats (Figure 4). The stark difference in proportions of livestock between the neighbouring countries of Georgia and Azerbaijan may be explained by their (largely) contrasting climates. The western parts of Georgia benefit from westerly airstreams originating over the Black Sea and the orographic effect of the Caucasus Mountains, and can receive more than $2500 \mathrm{~mm}$ of rainfall each year (Connor and Kvavadze 2008; Ye 2001). The mountain ranges form a rain-shadow over much of eastern Georgia, which can receive as little as $400 \mathrm{~mm}$ annually, and further eastward into the semidesert lowlands of Azerbaijan annual precipitation varies from $\sim 1100 \mathrm{~mm}$ in the northwest to $\sim 250 \mathrm{~mm}$ in the east (Connor and Kvavadze 2008; Mamedov et al. 2009). The contrast in climate between western and eastern Georgia can be seen in the precipitation data presented from (humid) Batumi and (arid) Tbilisi in Table 1.

In the archaeological data, the contribution of horse bones to the Iron Age assemblages mirrors the pattern seen in the sheep/goat material of this period, with horses well represented in the northern Trans-Ural and pre-Ural region and poorly represented in south-east Kazakhstan (Figure 3C). In general, in the later prehistoric assemblages, we see a pattern in which the proportion of horses increases at higher latitudes.

The cold and dry eastern steppe, in particular, suffers from often snowy winters, with snow depth of around $30 \mathrm{~mm}$ in the southern semi-desert zone, and higher in the northern steppe (Kerven 2004). The higher precipitation to the north (Ye 2001) means that during winter these areas receive higher quantities of snowfall. Only horses can really survive on natural pastures in winter, as they can forage in up to $50 \mathrm{~cm}$ of snow, by kicking it away (Kerven 2004; Kerven et al. 1996; Shnirelman et al. 1996). Horses are adapted particularly well to cold, snowy conditions, as seen by the extreme conditions that the Yakut horse can withstand (Ferret 2009; Anufriev et al. 2009).

In the modern data, the proportions of horses are relatively small across the entire steppe region, varying between 0.7 and $9.5 \%$ of livestock. The lowest values are in the hotter and more arid countries of Uzbekistan and Azerbaijan (Figure 4). The generally low presence of horse across all countries may be attributed to reductions in the consumption of horse meat in modern times and the replacement of horsepower by mechanized transport and farm equipment (e.g. Ferret 2009). However, in the historic samples, from the Trans-Ural region (Figure 5, samples M, N, O, and P) and from northern Kazakhstan (samples I and Q) we see horses better represented in herds, constituting over $30 \%$ of livestock. The animal population data from across the southern area of the study region - such as Uzbekistan (sample D), and north-west China (samples J and K) all agree with the proportions of modern livestock kept in these regions.

\section{Discussion}

This paper presents a simple comparison of the representation of domestic cattle, sheep/goats and horses from geographically distinct regions. In part, the different 
dating of the archaeological assemblages selected for comparison in this paper limits their comparability, as long term changes in the climate will have affected the positions of landscape and vegetational zone boundaries, which thus may have influenced the ratios of species kept in certain geographical areas (e.g. Kotova and Makhortykh 2010; Kremenetski 2003). However, the comparison of the later prehistoric animal bone assemblages and the modern and historic livestock herd compositions (Figures 2, 4 and 5) show a number of consistencies indicating the strong influence of the environment on the pastoral economies practiced across the Eurasian steppe.

There are strong biases towards different taxa dependent on region, however, all species are present in each region. The maintenance of several livestock species may be seen as a means of spreading risk in pastoral economies (Fernandez-Gimenez 1999; Pratt 1984). The specific regional climatic, topographical and ecological conditions would have influenced decisions as to which proportions of each animal were herded according to their particular biological and behavioural characteristics. Knowledge of these variables may therefore help in the interpretation of past pastoral economies, and in exploring the possible environmental and cultural factors affecting them. In terms of species proportions at sites in a particular region (Figures 2 and 3), for example, how do we explain sites which clearly plot as outliers from their group? Could these represent sites where particular interventions were practiced, such as the provision of shelter, additional feed, or the following of nomadic movements? Could these be sites at which animals were herded against environmental odds because of the status awarded to them (e.g. Pratt 1984)? Interventions by humans - provision of shelter and fodder increases the survivability of domestic animals through winters (Ferret 2009; Kerven 2004). The use of mobile pastoral strategies also allows the use of seasonally available, geographically-discrete, resources (Kerven 2004; Sneath 1999). Before the $19^{\text {th }}$ century AD Russian settlement and colonisation, Kazakhs did not provide supplementary fodder for their animals, but rather moved between ecological zones to seasonal pastures (Kerven et al. 1996). In contemporary and historic pastoral movement systems, distances and patterns of seasonal movements vary considerably across Central Asia, ranging from a few kilometres to over one thousand (Ferret 2009; Sneath 1999; Shnirelman et al. 1996; Vainshtein 1980). It is the modern environmental conditions of the Eurasian steppe that have been outlined above and future work should in particular focus on defining the conditions across the study area in later prehistory, so that potential relationships between species use and climate and vegetation mosaics can be assessed in detail.

Better understanding of the constraints on regional economies created by the particular species characteristics and local environmental conditions could thus enable us to address a range of questions relating to past societies and economies. The need for adaptation of livestock systems is recognised for modern communities in developing countries experiencing changes in their climates (Thornton et al. 2009), and this approach may also allow assessment of the adaptation of prehistoric economies and organisms to changing conditions. How quickly did animals originating from one environment adapt to new environments (e.g. Kay 1997; Thornton et al. 2009), such as animal populations originating from the Near East adapting to the more extreme conditions of the eastern steppe? How did this influence the rate and direction of spread of pastoral economies as evidenced in the archaeological record, and relate to the 
mechanisms for the spread of these economies (e.g. Zvelebil 1986; Harris 1996)? By starting with this large scale approach we can progressively add such variables and details to explore the nuances of the spread and developments of pastoral systems in the past. This paper has presented preliminary work; the next step is to collect archaeozoological data pertaining to all animal species used without geographical or chronological restrictions across the steppe, taking into account possible changes in climate and vegetation mosaics through time as well the details of the cultural contexts, to explore the origins, spread and development of pastoral economies throughout the Eurasian steppe.

\section{Acknowledgements}

I would especially like to thank Rebecca Oakes and the two anonymous reviewers for helpful comments on a previous version of this paper, Pavel Kosintsev for sending me publications and data, and the FAOSTAT team for permission to use the modern livestock data.

\section{Author details}

${ }^{1}$ Muséum national d'Histoire naturelle, UMR 7209 du CNRS « Archéozoologie, archéobotanique: sociétés, pratiques et environnements », Département Écologie et Gestion de la Biodiversité, USM 303, Case postale Nº 56 (Bâtiment d'anatomie comparée), 55 rue Buffon, F-75231 Paris cedex 05, France ²Department of Archaeology, University of Reading, Whiteknights Box 226, Reading, RG6 6AB, UK

\section{Authors' information}

Following a PhD examining the archaeology of the horse in Britain, the author spent three years at the Muséum national d'Histoire naturelle, Paris, studying aspects of prehistoric pastoral economies of Central Asia and Europe. He is currently working at Reading University, UK, as the archaeozoologist on a project investigating early animal husbandry in the Zagros Mountains of Iran http://www.czap.org/.

\section{Competing interests}

The author declares that they have no competing interests.

Received: 1 February 2011 Accepted: 9 May 2011 Published: 9 May 2011

\section{References}

Anthony, DW. 2007. The horse, the wheel and language. Princeton and Oxford: Princeton University Press.

Anufriev, Al, VF Yadrikhinskii, and AP Isaev. 2009. Body temperature in purebred and hybrid Yakut horses under the conditions of Yakutia. Doklady Biological Sciences 427: 358-361.

Barker, G. 2006. The agricultural revolution in prehistory: why did foragers become farmers? Oxford: Oxford University Press. Benecke, N. 2003. Iron Age economy of the Inner Asian steppe. A bioarchaeological perspective from the Talgar Region in the Ili River Valley (Southeastern Kazakhstan). Eurasia Antiqua 9: 63-84.

Benecke, N, and A von den Driesch. 2003. Horse exploitation in the Kazakh steppes during the Eneolithic and Bronze Age. In Prehistoric steppe adaptation and the horse, ed. Levine M, Renfrew C, Boyle K 69-82. Cambridge: McDonald Institute for Archaeological Research.

de Beurs, KM, and GM Henebry. 2004. Land surface phenology, climatic variation, and institutional change: Analyzing agricultural land cover change in Kazakhstan. Remote Sensing of Environment 89: 497-509.

Boessneck, J. 1969. Osteological differences between sheep (Ovis aries Linné) and goat (Capra hircus Linné). In Science in Archaeology, ed. Brothwell D, Higgs E 331-58. London: Thames and Hudson.

Connor, SE, and EV Kvavadze. 2008. Modelling late Quaternary changes in plant distribution, vegetation and climate using pollen data from Georgia, Caucasus. Journal of Biogeography 36: 529-545.

Cucchi, T, A Hulme-Beaman, J Yuan, and K Dobney. 2011. Early Neolithic pig domestication at Jiahu, Henan Province, China: clues from molar shape analyses using geometric morphometric approaches. Journal of Archaeological Science 38: $11-22$.

Dolukhanov, PM. 2002. Alternative revolutions: hunter-gatherers, farmers and stock-breeders in the Northwestern Pontic area. In Ancient interactions: east and west in Eurasia, ed. Boyle K, Renfrew C, Levine M 13-14. Cambridge: McDonald Institute Monographs.

Dolukhanov, PM. 1986a. The Late Mesolithic and the Transition to food production in Eastern Europe. In Hunters in transition: Mesolithic societies of temperate Eurasia and their transition to farming, ed. Zvelebil M 109-119. Cambridge: Cambridge University Press.

Dolukhanov, PM. 1986b. Foragers and farmers in west-central Asia. In Hunters in transition: Mesolithic societies of temperate Eurasia and their transition to farming, ed. Zvelebil M 121-132. Cambridge: Cambridge University Press.

FAOSTAT 2010. FAOSTAT Food and Agriculture Organization On-line Databases. http://faostat.fao.org/default.aspx. Accessed August 2010.

Fernandez-Gimenez, ME. 1999. Sustaining the Steppes: A Geographical History of Pastoral Land Use in Mongolia. Geographical Review 89: 315-342.

Ferret, C. 2009. Une civilisation du cheval. Paris: Belin. 
Frachetti, M. 2008. Pastoralist landscapes and social interaction in Bronze Age Eurasia. Berkeley (CA): University of California Press.

Frachetti, M, and N Benecke. 2009. From sheep to (some) horses: 4500 years of herd structure at the pastoralist settlement of Begash (south-eastern Kazakhstan). Antiquity 83: 1023-1037.

Harris, DR. 2010. Origins and Agriculture in Western Central Asia: An Environmental-Archaeological Study. Philadelphia: University of Pennsylvania Museum of Archaeology and Anthropology.

Harris, DR. 1996. The origins and spread of agriculture and pastoralism in Eurasia: an overview. In The Origins and Spread of Agriculture and Pastoralism in Eurasia, ed. Harris DR 552-573. London: UCL Press.

Hiebert, FT. 2002. Bronze Age interactions between the Eurasian steppe and Central Asia. In Ancient interactions: east and west in Eurasia, ed. Boyle K, Renfrew C, Levine M 237-248. Cambridge: McDonald Institute Monographs.

IAEA/WMO 2006. Global Network of Isotopes in Precipitation. The GNIP Database. http://isohis.iaea.org. Accessed August 2010.

Kay, RNB. 1997. Responses of African livestock and wild herbivores to drought. Journal of Arid Environments 37: 683-694.

Kerven, C. 2004. The influence of cold temperatures and snowstorms on rangelands and livestock in northern Asia. In Rangelands at Equilibrium and Non-equilibrium, VII International Rangelands Congress, Programme for Land and Agrarian Studies, ed. Vetter S 41-55. RAS: University of Western Cape.

Kerven, C, J Channon, and R Behnke. 1996. Planning and policies on extensive livestock development in Central Asia (Overseas Development Institute Working Paper 91). London: Overseas Development Institute.

Kislenko, A, and N Tatarintseva. 1999. The Eastern Ural steppe at the end of the Stone Age. In Late Prehistoric Exploitation of the Eurasian Steppe, ed. Levine MA, Rassamakin Y, Kislenko A, Tatarintseva N 183-216. Cambridge: McDonald Institute for Archaeological Research.

Kohl, PL. 2007. The making of Bronze Age Eurasia. Cambridge: Cambridge University Press.

Koryakova, L, and AV Epimakhov. 2007. The Urals and western Siberia in the Bronze and Iron Ages. Cambridge: Cambridge University Press.

Koryakova, L, and B Hanks. 2006. Horse husbandry among the Early Iron Age Trans-Ural Societies. In Horses and Humans: the evolution of human-equine relationships, ed. Olsen SL, Grant S, Choyke AM, Bartosiewicz L 275-287. Oxford: Archaeopress.

Kosintsev, PA. 2006. The Human-Horse Relationship on the European-Asian Border in the Neolithic and Early Iron Age. In Horses and Humans: the evolution of human-equine relationships, ed. Olsen SL, Grant S, Choyke AM, Bartosiewicz L 127-135. Oxford: Archaeopress.

Kosintsev, PA. 2002. Typology of mammalian assemblages of the forest-steppe regions near the Ob-river, reconstructed from the human settlements of the Bronze Age. In Urals fauna at Pleistocene and Holocene, ed. Kosintsev P 162-166. Ekaterinburg: University. [In Russian: Kosintsev, P.A. 2002. Типология териокомплексов лесостепного приобья из поселений эпохи бронзы In Фауна Урала в плейстоцене и голоцене, ed. P. Kosintsev, 162-166. Екатеринбург: Университет].

Kotova, N, and S Makhortykh. 2010. Human adaptation to past climate changes in the northern Pontic steppe. Quaternary International 220: 88-94.

Krader, L. 1955. Ecology of Central Asian Pastoralism. Southwestern Journal of Anthropology 11: 301-326.

Kremenetski, KV. 2003. Steppe and forest-steppe belt of Eurasia: Holocene Environmental History. In Prehistoric steppe adaptation and the horse, ed. Levine M, Renfrew C, Boyle K 11-27. Cambridge: McDonald Institute for Archaeological Research.

Kushnareva, KKh. 1997. The southern Caucasus in prehistory: stages of cultural and socioeconomic development from the eighth to the second millennium BC. Philadelphia: The University Museum.

Larson, G, K Dobney, U Albarella, M Fang, E Matisoo-Smith, J Robins, S Lowden, H Finlayson, T Brand, E Willerslev, P RowleyConwy, L Andersson, and A Cooper. 2005. Worldwide phylogeography of wild boar reveals multiple centers of pig domestication. Science 307: 1618-1621.

Levine, MA. 2005. Origins and selection of horse behaviour. In The domestic horse: the origins, development and management of its behaviour, ed. Mills D, McDonnell S 5-22. Cambridge: Cambridge University Press.

Lioubimtseva, E, and GM Henebry. 2009. Climate and environmental change in arid Central Asia: Impacts, vulnerability, and adaptations. Journal of Arid Environments 73: 963-977.

Lyman, RL. 1994. Vertebrate taphonomy. Cambridge: Cambridge University Press.

Mamedov, RM, SG Safarov, and ES Safarov. 2009. Current changes of the atmospheric precipitation regime on the territory of Azerbaijan. Geography and Natural Resources 30: 403-407.

Matyushin, G. 2003. Problems of inhabiting central Eurasia: Mesolithic-Eneolithic Exploitation of the central Eurasian steppes. In Prehistoric steppe adaptation and the horse, ed. Levine M, Renfrew C, Boyle K 367-393. Cambridge: McDonald Institute for Archaeological Research.

Matyushin, G. 1986. The Mesolithic and Neolithic in the southern Urals and Central Asia. In Hunters in transition: Mesolithic societies of temperate Eurasia and their transition to farming, ed. Zvelebil M 133-150. Cambridge: Cambridge University Press.

Morales Muniz, A, and E Antipina. 2003. Srubnaya faunas and beyond: a critical assessment of the archaeozoological information from the East European steppe. In Prehistoric steppe adaptation and the horse, ed. Levine M, Renfrew C, Boyle K 329-351. Cambridge: McDonald Institute for Archaeological Research.

Nardone, A, B Ronchi, N Lacetera, and U Bernabucci. 2006. Climatic effects on productive traits in Livestock. Veterinary Research Communications 30(Suppl 1): 75-81.

O'Connor, TP. 2010. Livestock and deadstock in early medieval Europe from the North Sea to the Baltic. Environmental Archaeology 15: 1-15.

Olsen, SL. 2006. Early horse domestication: weighing the evidence. In Horses and Humans: the evolution of human-equine relationships, ed. Olsen SL, Grant S, Choyke AM, Bartosiewicz L 81-113. Oxford: Archaeopress.

Outram, AK, NA Stear, A Kasparov, E Usmanova, V Varfolomeev, and RP Evershed. 2011. Horses for the dead: funerary foodways in Bronze Age Kazakhstan. Antiquity 85: 116-128.

Outram, A, N Stear, R Bendrey, S Olsen, A Kasparov, V Zaibert, N Thorpe, and R Evershed. 2009. The Earliest Horse Harnessing and Milking. Science 323: 1332-1335. 
Payne, S. 1985a. Morphological distinctions between the mandibular teeth of young sheep, Ovis, and goats, Capra. Journal of Archaeological Science 12: 139-147.

Payne, S. 1985b. Zoo-archaeology in Greece: a reader's guide. In Contributions to Aegean archaeology, ed. Wilkie NC, Coulson WDE 211-244. Minneapolis: University of Minnesota.

Popova, LM. 2006. Pastoralism during the Late Bronze Age in Russia: past interpretations and new goals for future research. In Beyond the steppe and the sown, ed. Peterson DL, Popova LM, Smith AT 459-468. Leiden and Boston: Brill.

Pratt, DJ. 1984. Arid Africa. In Development of animal production systems, ed. Nestel B 155-164. Amsterdam: Elsevier.

Shnirelman, VA, SL Olsen, and P Rice. 1996. Hooves across the steppe: the Kazak life-style. In Horses through Time, ed. SL Olsen 129-152. Boulder, Colorado: Roberts Rinehart Publishers.

Silanikove, N. 2000. The physiological basis of adaptation in goats to harsh environments. Small Ruminant Research 35: 181-193.

Sneath, D. 1999. Spatial mobility and Inner Asian pastoralism. In The end of Nomadism?: society, state, and the environment in Inner Asia, ed. Humphrey C, Sneath D 218-277. Durham, USA, Cambridge, UK: Duke University Press.

Sternberg, T, D Thomas, and N Middleton. 2010. Drought dynamics on the Mongolian steppe, 1970-2006. International Journal of Climatology.

Temple, RS. 1984. Livestock populations and factors affecting them. In Development of animal production systems, ed. Nestel B 33-61. Amsterdam: Elsevier.

Thornton, PK, J van de Steeg, M Notenbaert, and A Herrero. 2009. The impacts of climate change on livestock and livestock systems in developing countries: a review of what we know and what we need to know. Agricultural Systems 101: $113-127$.

Tresset, A, and J-D Vigne. 2011. Last hunter-gatherers and first farmers of Europe. Comptes Rendus Biologies 334: 182-189. Vainshtein, SI. 1980. Nomads of South Siberia: the pastoral economies of Tuva. Cambridge: Cambridge University Press.

Vigne, JD. 2011. The origins of animal domestication and husbandry: A major change in the history of humanity and the biosphere. Comptes Rendus Biologies 334: 171-181.

Ye, H. 2001. Characteristics of Winter Precipitation Variation over Northern Central Eurasia and Their Connections to Sea Surface Temperatures over the Atlantic and Pacific Oceans. Journal of Climate 14: 3140-3155.

Zeder, MA. 2008. Domestication and early agriculture in the Mediterranean Basin: origins, diffusion, and impact. Proceedings of the National Academy of Sciences 105: 11597-11604.

Zvelebil, M. 1986. Mesolithic societies and the transition to farming: problems of time, scale and organization. In Hunters in transition: Mesolithic societies of temperate Eurasia and their transition to farming, ed. Zvelebil M 167-188. Cambridge: Cambridge University Press.

Zvelebil, M, and M Lillie. 2000. Transition to agriculture in eastern Europe. In Europe's first farmers, ed. Price TD 57-92. Cambridge: Cambridge University Press.

doi:10.1186/2041-7136-1-8

Cite this article as: Bendrey: Some like it hot: environmental determinism and the pastoral economies of the later prehistoric Eurasian steppe. Pastoralism: Research, Policy and Practice 2011 1:8.

\section{Submit your manuscript to a SpringerOpen ${ }^{\odot}$ journal and benefit from:}

- Convenient online submission

- Rigorous peer review

- Immediate publication on acceptance

- Open access: articles freely available online

- High visibility within the field

- Retaining the copyright to your article

Submit your next manuscript at $\boldsymbol{s p r i n g e r o p e n . c o m ~}$ 